\title{
An investigation into English language use in the Vietnamese hospitality industry: The language of money exchange
}

\author{
Vu Thi Hong Van ${ }^{1 *}$ \\ ${ }^{1}$ Ho Chi Minh City University of Education, Vietnam \\ *Corresponding author: vuthihongvandhsp@yahoo.com
}

\begin{tabular}{|c|c|}
\hline ARTICLE INFO & ABSTRACT \\
\hline $\begin{array}{l}\text { DOI:10.46223/HCMCOUJS. } \\
\text { soci.en.8.2.279.2018 }\end{array}$ & $\begin{array}{l}\text { Within the tourism and hospitality industry in Vietnam, } \\
\text { English is now a dominant means of communication between } \\
\text { staff and guests who come from different countries. The ability } \\
\text { to communicate effectively in English is therefore an important } \\
\text { attribute for those employed within the industry. Courses in } \\
\text { English for Specific Purposes (ESP), such as English for } \\
\text { Tourism and Hotel (English for Tourism Management/English } \\
\text { for Hotel Management), are now part of English language } \\
\text { programmes in Vietnamese educational institutions. These } \\
\text { courses emphasise the importance of developing high-level } \\
\text { English language communication skills for students. However, }\end{array}$ \\
\hline Received: October $31^{\text {st }}, 2018$ & the teaching of these courses has mainly been conducted in the \\
\hline Revised: November $28^{\text {th }}, 2018$ & classroom environment, using textbooks which are written and \\
\hline Accepted: December $6^{\text {th }}, 2018$ & $\begin{array}{l}\text { focused on the need to teach language as it is used in authentic } \\
\text { contexts, it is important for the teaching of ESP to understand } \\
\text { how English is used in a real-life setting in the Vietnamese } \\
\text { tourism and hospitality sector. }\end{array}$ \\
\hline & $\begin{array}{l}\text { This paper reports on the findings from a study which } \\
\text { obtained and analysed hundreds of examples of the authentic } \\
\text { English language used by guests and staff in four different hotels } \\
\text { in Vietnam. For illustrative purposes, the paper focuses on the }\end{array}$ \\
\hline $\begin{array}{l}\text { Keywords: } \\
\text { authentic mate } \\
\text { tourism and ho }\end{array}$ & $\begin{array}{l}\text { language of interactions related to currency exchange, and } \\
\text { examines the implications of the study findings for the teaching } \\
\text { of ESP in Vietnam. }\end{array}$ \\
\hline
\end{tabular}

\section{Introduction}

Economic globalisation and the development of technology have fuelled the spread of English and enhanced its dominant position as a world language for communication in a variety of settings. Its penetration and predominance can be recognised in worldwide business, finance, commerce, science, politics, cultural exchanges, education and technology (Kirkpatrick, 2007; Nickerson, 2005; John, 1996). English has become a lingua franca in global business in various situations such as meetings, negotiations, marketing, and telephone calls, or in daily communication within intranational and international corporations, and has spread on an unprecedented scale (Charles, 2007). According to Pullin (2010), 90 percent of communication 
in business is taking place worldwide in English. Rogerson-Revell (2007) also indicates that English has become an official corporate language for large as well as small companies within Europe and internationally. For many in the workplace, English is seen as a substantial contributor to successful business negotiations (Forey, 2004). English has also been used as an official working language of many international organizations. According to Crystal (1997), about 85 percent of international organisations worldwide use English as the primary working language. These include the United Nations (UN), Asia-Pacific Economic Cooperation (APEC), Association of Southeast Asian Nations (ASEAN), European Union (EU), International Monetary Fund (IMF), South Asian Association for Regional Cooperation (SAARC), and the World Trade Organisation (WTO).

In service encounters such as tourism and hospitality, English is an important factor in facilitating business. It has become the dominant form of communication in cross-cultural communication settings within the tourism and hospitality industry (Blue \& Harun, 2003). Most worldwide websites and tour programmes, as well as advertisements for tourism, are expressed in English. Moreover, in restaurants, hotels, travel agencies, entertainment and shopping centres, on airplanes, at the airports, or at the ticket cashier, in daily communications within this industry, English is frequently used. Tourism itself has become one of the greatest and the fastest growing sectors worldwide, and employs the largest number of staff in any sector.

The global development of tourism has had a great influence on developing countries like Vietnam. With favourable conditions such as great natural scenery and a tropical climate, Vietnam has a lot of advantages for the development of tourism. Thanks to the Government's open-door policy, Doi Moi, which came into existence in 1986, the economy of the country has shifted from an agrarian to a free, market-oriented economy, and the country has expanded its relationships and cooperated with many countries in the world in different domains. This has helped to attract a number of foreign visitors coming to Vietnam as tourists and business people. Accordingly, the tourism and hospitality service industry has developed and become a spearhead of the country's economic growth.

Within that context, competent communication in English is a demand for those who will work in the industry as receptionists, tour guides, tour operators, housekeepers, restaurant staff and security staff. Developing and improving students' communication skills in English, therefore are an emphasis in all educational institutions which provide programs in tourism and hospitality. English for Tourism and Hotel, as a sub-category of English for Specific Purposes (ESP), has been taught in all courses of tourism and hospitality, and it occupies around 180 and 240 classroom hours depending on each school's curriculum design. The teaching of these ESP courses has mainly been conducted in the classroom environment using textbooks which are written and published outside Vietnam. Examples of textbooks commonly used to teach English for tourism in Vietnam include First Class - English for Tourism, English for International Tourism, Highly Recommended, High Season, International Hotel English, and Tourism. While these textbooks fulfill a valuable function, it is essential to recognise that the language of the ESP classroom needs to reflect the language of workplace settings, and it is unlikely that textbooks will "reflect the communication reality in which the students actually have to function" (Seedhouse, 2005, p. 169). Burns (1998), Carter and McCarthy (1995), Koester 
(2002), and Wong (2002) have all placed emphasis on the value of authentic teaching materials. Schegloff, Koshik, Jacoby, and Olsher (2002) also argue that "textbooks using invented dialogue based on intuitions of how certain language functions are accomplished do not always offer students accurate knowledge of language use" (p. 17). In short, it has been argued that to teach the language appropriately, we must know the language to teach, and the language to be taught has to be derived from authentic contexts (Vu \& Dunworth, 2013). For that reason, it is necessary to see to what extent the English language is authentically used in real-life settings within the Vietnamese Tourism and Hospitality industry. This study set out to examine the characteristics of the English language used within the Vietnamese tourism and hospitality industry and examine the implications this kind of language has for the teaching of ESP.

\section{The study}

The aims of this study were to identify the communicative patterns of speech used within the Vietnamese hospitality industry and explore the implications of the findings for the teaching of ESP in Vietnam.

The data used for the study were hundreds of authentic conversations in English between hotel staff and guests recorded at four hotels in Ho Chi Minh City, Vung Tau and Phan Thiet. The conversations were recorded primarily at the front office counters - the reception and the concierge areas - but samples were also obtained from restaurant and bar areas. All recorded interactions were transcribed using the transcription conventions primarily developed by Jefferson as described in Wray and Aileen (2013) (see conventions of transcription below) and numbered after every five lines for easy observation.

\section{Key to Transcription Symbols}

?

- falling intonation

/

//

$[*]$

$-$

,

word

speaker

rising intonation

speaker emphasis pause of up to 0.5 second

pause of approximately 0.5 second to approximately 1.5 seconds

filled pause (e.g., er or um)

truncation (e.g., what ti- what time is it)

continuing at the end of the clause

a rise in pitch in a stressed syllable

Conversation analysis (CA) as a research approach which is used to discover the natural organisation, the structure of interaction and the mechanisms that embody the underlying organisation of talk-in-interaction (Psathas, 1995) was used for analysing the data in this study. The ontological position of CA is that of social constructivism, and it emphasises the way social reality is negotiated and locally achieved through talk (Clifton, 2006). The main focus of CA is on social interaction, the collaborative construction of meaning, and the discovery of emerging patterns from the data. $\mathrm{CA}$ is interested in the shared knowledge participants have and the way 
they use this knowledge to complete the activities at work (Clifton, 2006). In other words, the focus of CA is the way participants display and construct a mutual understanding in talk-ininteraction, or as what Hutchby and Wooffitt (1998) observe in CA that its aim is "to discover how participants understand and respond to one another in their turn at talk" (p. 6). Employing CA, the analysis must be "bottom-up and data-driven" (Seedhouse, 2005, p. 167), therefore, a researcher should not impose any pre-determined categories or theories on the data as any conclusions made in the study have to emerge from the data (Seedhouse, 2004, 2005; Wardhaugh, 2010).

As the aim of this study was to uncover the communicative patterns and the characteristics of the language used within the Vietnamese hospitality industry, the approach taken to data analysis was that of unmotivated observation. To illustrate the findings, the language of interactions related to the currency exchange has been selected for this paper, although the data themselves produced rich examples of multiple contexts of use.

Sequences of related talk have been extracted from the transcripts to illustrate the way in which staff and guests negotiated when the transaction was on. Bold font is used to identify the communicative strategies employed by the staff and guests in their interactions. An arrow $(\rightarrow)$ is used before the utterance within which the strategy is focused.

From observation, interactions related to currency exchange frequently followed a transactional procedure which could include:

- Greetings;

- Request for a service;

- Clarification of the currency exchanged;

- Agreement on the rate of exchange;

- Request for a signature;

- Completion of the transaction.

The interaction was initiated either by the staff or guests, and in many cases, openings were marked by staff's formal greetings, such as "Good afternoon" or "Good morning sir/madam", or offers of assistance, such as "May I help you sir?" or "Can I help you (sir)?" which are responded either by a guest's greeting or a request for service. The extracts below provide examples of these patterns.

\section{Extract 1}

[1] S: good afternoon sir?

[2] G: can you change this?

\section{Extract 2}

[1] S: good evening / yes sir?

[2] G1: we want to change money please 


\section{Extract 3}

[1] S: good morning

[2] G: can I change some money please?

\section{Extract 4}

[1] S: ah / can I help you?

[2] G1: could you please change?

\section{Extract 5}

[1] S: yes can I help you sir?

[2] G: change

In other cases, guests approached the counter and started the conversation with a direct request for a service or information such as "can you change money? which was followed by a staff"s affirmative reply "yes", or an offer of assistance "May I help you sir?".

After the opening, the interaction was generated and continued until the communicative outcome was achieved. The language used by the staff and guests was simple including a single word, a word group (phrase), or short utterances. In some cases, the transaction was longer and it took several turns, for example, to have the exchange rate agreed on between staff and guest. While the language was simple, strategies such as repetition or reformulation were frequently used by staff and guests to promote comprehension. The examples below illustrate this process.

\section{Extract 6}

[1] S: may I help you sir?

G: can you change money

S: yes

G: euros into dong

[5] S: $\rightarrow$ it's cost // euros

G: [*] it's in the bank today it's fifty seven

S: today it's down.

G: okay. // I want to change in dong not to dollars

S: yes I see // yeah / ok?

[10] G: huh? how much is a hundred? // [*] two / two million, five hundred, fifty / thousand / it's okay. ((laughing))

$\mathrm{S}$ : one million, / two million,

G: yeah okay ((laughing)) // thank you.

S: you're welcome 
In this interaction, the staff member started the conversation with an offer of assistance which was followed by the guest's direct request for an exchange service: "Can you change money" from 'euro' into the local currency 'dong'. The staff member might show the rate of exchange to the guest as indicated in the interaction by "it's cost // euros" (line 5) to which the guest then reacted by giving proof from the bank for the rate of exchange "it's in the bank today it's fifty seven" (line 6). The transaction was generated over several turns and continued until acceptance to be obtained and marked by the guest's response "it's okay" and the laughter in line 11. The transaction was completed by the staff member's action of handling the exchanged currency to the guest followed by the guest's repetition of what had been said in prior turn (line 11) and a closing 'thank you'.

In the following exchange, the transaction was generated over a sequence of turns. Repetition of the interlocutor's prior utterance was employed until the final outcome was achieved.

\section{$\underline{\text { Extract } 7}$}

[1] G: you are ok?

S: yes?

G: have you got the cost?

$\mathrm{S}: \rightarrow$ cost?

[5] G: yes

S: euro or dollar?

G: one one euro

$\mathrm{S}: \rightarrow$ euro? /// ok?

G: ok/ thank you

In a more extended exchange, there was greater repetition and reformulation of what was said or heard by both guests and staff in each turn throughout the interaction as illustrated in the example below.

\section{Extract 8}

[1] G: can you change money?

S: yes? / it's down today.

$\mathrm{G}: \rightarrow$ fall down? / lost

$\mathrm{S}: \rightarrow$ no no/ I say the euro/ the euro money/ it fall down / lower

[5] G: and then I'm changes dollar and then in / changes in in dong // is it more? 
S: $\rightarrow$ you means the euro? / you change to Vietnam dong/ it's low/ it's low // if you change to dollar it's no // do- euro you change to dollar the same but-

[10] G: $\rightarrow$ the same

$\mathrm{S}: \rightarrow$ yeah/ but from euro/ you change to Vietnam dong// it's very low/ yeah.

However, in some cases, the transaction was completed very quickly over a couple of turns as illustrated in the following interaction.

\section{Extract 9}

[1] S: please your room number? // please sign here sir? /// one million three hundred and $[*]$ thirty // thousand dong?

[2] G: uh huh? / yes / thank you

In this interaction, the guest might simply place the money he or she wanted to exchange on the counter. The staff member then asked for the guest's details and the transaction was completed in a single turn with the guest's closing markers "uh huh? / yes / thank you".

From the extracts analysed above, it can be argued that the language of interactions related to currency exchange is transactional, informative and procedural, and it is characterised by short, straightforward and goal-oriented utterances performed by the staff and guests in their talk. The utterances may appear in a form of a single word, a phrase or a short sentence, and tend to be coupled within pairs such as offer-response (May I help you? - Could you please change? (Extract 4); Can I help you sir? - Change (Extract 5), greeting - greeting (Good afternoon - Hello), or sequences of turns which are inter-related, i.e., the following utterance is produced depending on the preceding. The staff and guests employed various strategies such as repetition and reformulation of what was said or heard in an attempt to achieve mutual intelligibility and therefore achieve important communicative goals. Thus, CA has helped to reveal the way the staff and the guest jointly constructed their interaction.

It was observed that in many cases, formal greetings and the title 'Sir' were used by the staff to address male guests. Politeness markers, such as "May I", "Can I" were used by staff when offering help to guests; similarly, "Could you", "Can you" or "Can I" were the ways guests requested a service. In the same way, politeness markers "please" or "thank you" were frequently used by both staff and guests in their interactions. However, in many cases, the requests or responses uttered by both staff and guests were single words or phrases (e.g., "Change today?"; "Cost?"-"Euro or in dollar?"; "Fall down? / lost", etc.), and guests also approached the counter and initiated request directly without any polite preliminaries (e.g., "Change?"). In all exchanges observed, communication outcomes were always achieved and marked by affirmative responses "yes", "ok" accompanied by "thank you" or "thank you very much" uttered by guests at the closing stage. 


\section{Conclusion and implications}

Hospitality service is much concerned with communication and the quality of that service depends on the capacity of staff to perform a range of communicative functions. Information received and provided, therefore, must be the "right message for the right audience" (Wolvin, 1994, p. 195).

With the growth of tourism in Vietnam, it is important to promote high quality services in the industry in which an advanced level of communication in English is particularly emphasized. Particularly, in cross-cultural communication settings, when English is used as a lingua franca between people coming from different linguacultural backgrounds, it is necessary to provide students opportunities to be familiar with real-life settings where the actual communication in English takes place (Vu, 2015). Exposure to authentic work-place settings such as the hotel in this study gives an insight into what kind of English language is used, and it is the impetus for the suggestions that follow.

The language used in the real-life setting seems to be 'messy' and unlike the language presented in many textbooks used in ESP - English for Tourism/Hotel - courses (Vu, 2015). In the workplace settings, interactions are characterised by short, unfinished and 'ungrammatical' utterances, and staff and guests negotiate with one another to achieve their communicative goals by using different strategies as described above. Hence, to prepare ESP students for an environment in which interactional competence plays such an important role, it is suggested that considerable emphasis should be placed on developing and improving interactional strategies for students so that they know how to initiate and maintain the conversation with guests when working. Teaching materials and classroom pedagogy need to take this into account, i.e., should be modified and adapted to be suitable to the Vietnamese context. It is a particular focus when many (if not most) interactions in English take place between staff and guests whose first language is not English, grammatical accuracy and the development of a complex vocabulary repertoire (for example) may be rather less important than the ability to negotiate towards a successful interactional goal (Vu, 2015; Vu \& Dunworth, 2013).

\section{References}

Blue, G. M., \& Harun, M. (2003). Hospitality language as a professional skill. English for Specific Purposes, 22(1), 73-91. doi:10.1016/s0889-4906(01)00031-x

Burns, A. (1998). Teaching speaking. Annual Review of Applied Linguistics, 18, 102-123.

Carter, R., \& McCarthy, M. (1995). Grammar and the spoken language. Applied Linguistics, 16(2), 141-158. doi:10.1093/applin/16.2.141

Charles, M. (2007). Language matters in global communication. Journal of Business Communication, 44(3), 260-282.

Clifton, J. (2006). A conversation analytical approach to business communication. Journal of Business Communication, 43(3), 202-219.

Crystal, D. (1997). English as a global English. Cambridge, UK: Cambridge University Press. 
Forey, G. (2004). Workplace texts: Do they mean the same for teachers and business people? English for Specific Purposes, 23(4), 447-469. doi:10.1016/j.esp.2004.01.003

Hutchby, I., \& Wooffitt, R. (1998). Conversation analysis. Cambridge, UK: Polity Press.

John, M. J. S. (1996). Business is booming: Business English in the 1990s. English for Specific Purposes, 15(1), 3-18. doi:10.1016/0889-4906(95)00023-2

Kirkpatrick, A. (2007). The communicative strategies of ASEAN speakers of English as a lingua franca. In D. Prescott (Ed.), English in Southeast Asia: Varieties, literacies and literatures (pp. 118-136). Newcastle, UK: Cambridge Scholars Publishing.

Koester, A. J. (2002). The performance of speech acts in workplace conversations and the teaching of communicative functions. System, 30(2), 167-184. doi:10.1016/S0346251X(02)00003-9

Nickerson, C. (2005). English as a lingua franca in international business contexts. English for Specific Purposes, 24(4), 367-380. doi:10.1016/j.esp.2005.02.001

Psathas, G. (1995). Conversation analysis: The study of talk-in-interaction. Thousand Oaks, CA: Sage.

Pullin, P. (2010). Small talk, rapport \& international communicative competence. Journal of Business Communication, 47(4), 455-476. doi:10.1177/0021943610377307

Rogerson-Revell, P. (2007). Using English for international business: A European case study. English for Specific Purposes, 26(1), 103-120. doi:10.1016/j.esp.2005.12.004

Schegloff, E. A., Koshik, I., Jacoby, S., \& Olsher, D. (2002). Conversation analysis and applied linguistics. Annual Review of Applied Linguistics, 22, 3-31. doi:10.1017/S0267190502000016

Seedhouse, P. (2004). Conversation analysis and language learning. Language Learning, 54(S1), 1-54.

Seedhouse, P. (2005). Conversation analysis and language learning. Language Teaching, 38(4), 165-187.

$\mathrm{Vu}, \mathrm{T} . \mathrm{H} . \mathrm{V}$. (2015). English as a lingua franca in the Vietnamese hotel industry: Communicative strategies and their implications for vocational education (Doctoral dissertation, Curtin University, Perth, Australia).

Vu, T. H. V., \& Dunworth, K. (2013). "May I help you?”: Investigating English use in the hospitality industry in Vietnam. Danang University Journal of Science and Technology, 2(63), 125-132.

Wardhaugh, R. (2010). An introduction to sociolinguistics (6th ed.). Oxford, UK: WileyBlackwell.

Wolvin, A. D. (1994). Communication in the hospitality industry. International Journal of Hospitality Management, 13(3), 195-199. doi:10.1016/0278-4319(94)90019-1

Wong, J. (2002). “Applying” conversation analysis in applied linguistics: Evaluating dialogue in English as a second language textbooks. International Review of Applied Linguistics, 40(1), 37-60.

Wray, A., \& Aileen, B. (2013). Projects in linguistics and language studies. Hoboken, NJ: Taylor and Franis. 